\title{
EVALUATION OF THE HYDROPOWER GENERATION POTENTIAL OF A DAM USING OPTIMIZATION TECHNIQUES: APPLICATION TO DOMA DAM, NASSARAWA, IN NORTH CENTRAL NIGERIA
}

Adebayo Wahab SALAMI*, Bolaji Fatai SULE, Tope Lacroix ADUNKPE, Ayanniyi Mufutau AYANSHOLA and Solomon Olakunle BILEWU

\section{Abstract}

Optimization models have been developed to maximize annual energy generation from the Doma dam, subject to the constraint of releases for irrigation, ecological purposes, the water supply, the maximum yield from the reservoir and reservoir storage. The model was solved with LINGO software for various mean annual inflow exceedence probabilities. Two scenarios of hydropower retrofitting were considered. Scenario 1, with the reservoir inflows at 50\%, 75\%, and $90 \%$ probabilities of exceedence, gives the total annual hydropower as $0.531 \mathrm{MW}$, $0.450 \mathrm{MW}$ and $0.291 \mathrm{MW}$, respectively. The corresponding values for scenario 2 were $0.615 \mathrm{MW}, 0.507 \mathrm{MW}$, and $0.346 \mathrm{MW}$ respectively. The study also considered increasing the reservoir's live storage to $32.63 \mathrm{Mm} 3$ by taking part of the flood storage so that the maximum draft increases to $7 \mathrm{Mm3}$. With this upper limit of storage and draft with reservoir inflows of 50\%, 75\% and $90 \%$ probabilities of exceedence, the hydropower generated increased to $0.609 \mathrm{MW}, 0.540 \mathrm{MW}$, and 0.347 MW respectively for the scenario 1 arrangement, while those of scenario 2 increased to $0.699 \mathrm{MW}, 0.579 \mathrm{MW}$ and $0.406 \mathrm{MW}$ respectively. The results indicate that the Doma Dam is suitable for the production of hydroelectric power and that its generation potential is between $0.61 \mathrm{MW}$ and $0.70 \mathrm{MW}$.
Address

1 Department of Water Resources and Environmental Engineering, P.M.B 1515, University of Ilorin, Ilorin, Nigeria

* Corresponding author: awsalami2009@gmail.com

Key words

- Doma River dam

- optimization,

- integration of hydropower turbine,

- power generation,

- retrofitting.

\section{INTRODUCTION}

An adequate power supply is a vital prerequisite for a nation's development because it plays an indispensable role in its socio-economic and industrial development. Over time Nigeria is developing as a country whose economic development largely depends on energy; the energy sector contributed about $11.78 \%$ to the gross domestic product (GDP) in the second quarter of 2014 (NBS, 2010). Access to electricity as a basic form of energy supply to the population is crucial for development. It is estimated that only about 10 percent of rural dwellers and about 40 percent of urban families have access to electricity and are effectively lacking a power supply over 60 percent of the time (NBS 2010, Kennedy - Darling et al., 2008). The extent of this problem is underlined by the fact that Nigeria is the largest purchaser of standby electricity generators in the world (Braimoh and Okedeyi, 2010).

The demand for electricity in Nigeria far outstrips the supply, which is epileptic in nature (Kareem et al., 2014).Currently, Nigeria's electricity generation capacity is within a range of $3.5 \mathrm{GW}$ to $4.5 \mathrm{GW}$, which is far short of the estimated long-term power demands of $25 \mathrm{GW}$ required to sustain economic growth and development (Adejumobi and Adebisi, 2011). Presently, Nigeria has 16 power 
generating plants, which supply electrical energy to the national grid. Of the 16 generating plants, 3 are hydroelectricity and 13 are thermal (gas/steam). At present, Nigeria has an installed electricity generation capacity for supply to the national grid of $12,522 \mathrm{MW}$, with an available capacity of only approximately 4,500 MW (Latham and Watkins, 2016). Seven of the sixteen generation stations are over 20 years old, and the average daily power generation is below $2,700 \mathrm{MW}$, which is far below the peak load forecast of 8,876MW (Sambo et al., 2009).

Nigeria has considerable potential hydropower sources exemplified by her large and small rivers and streams distributed all over the country with potential sites for hydropower schemes which can serve the urban and rural populations (Okoro, 2006). Hydropower currently accounts for about $32 \%$ of the total installed commercial electric power capacity with an overall large-scale potential (exploitable) in excess of $11,000 \mathrm{MW}$ (enough to solely power the current electricity demand in the country) (Zarma, 2006). For many years, the hydroelectricity supply in Nigeria has come from the Kanji, Jebba and Shiroro dams with capacities of 760MW, 578.4MW and 600MW (Sambo et al., 2009), respectively. Utilizing the hydropower potential of the rivers in Nigeria will not only meet the increasing energy demands of the country but also accelerate the development of these areas in terms of their social infrastructure. Nigeria still has 278 undeveloped sites for small hydropower production, with a total capacity of 734MW (UNIDO, 2012). An acceptable $60 \%$ utilization of the hydropower potential in Nigeria will increase power generation to around $12 \mathrm{GW}$, a figure that will stabilize electric power in Nigeria and increase industrial activity in the country (Manohar and Adeyanju 2009).
Arunkumar and Jothiprakash (2012) optimized the operations of the Koyna reservoir in India by maximizing the hydropower production; this was subject to the condition of satisfying the irrigation demands using a non-linear programming model. The hydropower production from the reservoir was analyzed for three dependable inflow conditions, representing wet, normal and dry years. For each dependable inflow condition, various scenarios were analyzed based on the constraints on the releases, and the results were compared. A study conducted (Salami and Sule, 2012) on the optimal water management modeling of the Kainji and Jebba hydropower systems on the River Niger in Nigeria has shown that an optimal energy of $5995.60 \mathrm{GWH}$ can be generated, which is about $41 \%$ higher than the average energy generation of $4261.12 \mathrm{GWH}$ obtained according to the historical records at the power plants. Nigeria is blessed with a number of rivers and streams, which are either seasonal or perennial; the Rivers Niger and Benue with several tributaries constitute the Nigerian river system, which offers some potential renewable sources of energy for large economically viable hydropower development; other major rivers include the Kaduna, Sokoto, Hadejia, Yobe, Gongola, Ogun, Osun, Imo, Cross River, etc. (Sule, 2003). The integration of hydropower turbines into the Doma dam is thus a small step further in the utilization of the enormous water resources of the nation. The main aim of this study is to evaluate the hydropower generation potential of the Doma dam using optimization techniques.

The location of the study area is presented in Fig. 1, while the main features of the dam are presented in Tab. 1.

Tab. 1 Details of the Doma Dam

\begin{tabular}{|c|c|c|}
\hline $\mathrm{S} / \mathrm{NO}$ & ITEM & DETAILS \\
\hline \multirow[t]{7}{*}{1} & General & \\
\hline & Name of parent river & River Ohina (tributary of River Mada) \\
\hline & Catchment area of the parent river at the Doma Dam site & $179.94 \mathrm{~km}^{2}$ \\
\hline & Hydrological zone & IV \\
\hline & Purpose & Irrigation \\
\hline & Other uses & Water Supply \\
\hline & Net irrigable area & 1,000 Hectares \\
\hline \multirow[t]{13}{*}{2} & Dam & \\
\hline & Type of Dam & Earthfill \\
\hline & Available head & $15.7 \mathrm{~m}$ \\
\hline & Maximum Height of Dam & $28.5 \mathrm{~m}$ (above the lowest point of the river) \\
\hline & Length of dam crest & $520 \mathrm{~m}$ \\
\hline & Width of dam at its foundation & $160 \mathrm{~m}$ \\
\hline & Width of dam at the crest & $18 \mathrm{~m}$ \\
\hline & Reservoir surface area (at N.W.L) & $2.2 \mathrm{~km}^{2}$ \\
\hline & Reservoir capacity (at N.W.L) & $37.5 \mathrm{Mm}^{2}$ \\
\hline & Live Storage & $30 \mathrm{Mm}^{3}$ \\
\hline & Dead Storage & $7.5 \mathrm{Mm}^{3}$ \\
\hline & Live Storage Elevation & 132m.a.s.1 \\
\hline & Dead Storage Elevation & 116.3m.a.s.1 \\
\hline \multirow[t]{3}{*}{3} & Spillway & \\
\hline & Type of Spillway & Morning Glory and Open Channel \\
\hline & Spillway Design Flood & $63 \mathrm{~m}^{3} / \mathrm{s}$ \\
\hline
\end{tabular}

Source: Lower Benue River Basin Development Authority, Makurdi (2015) 


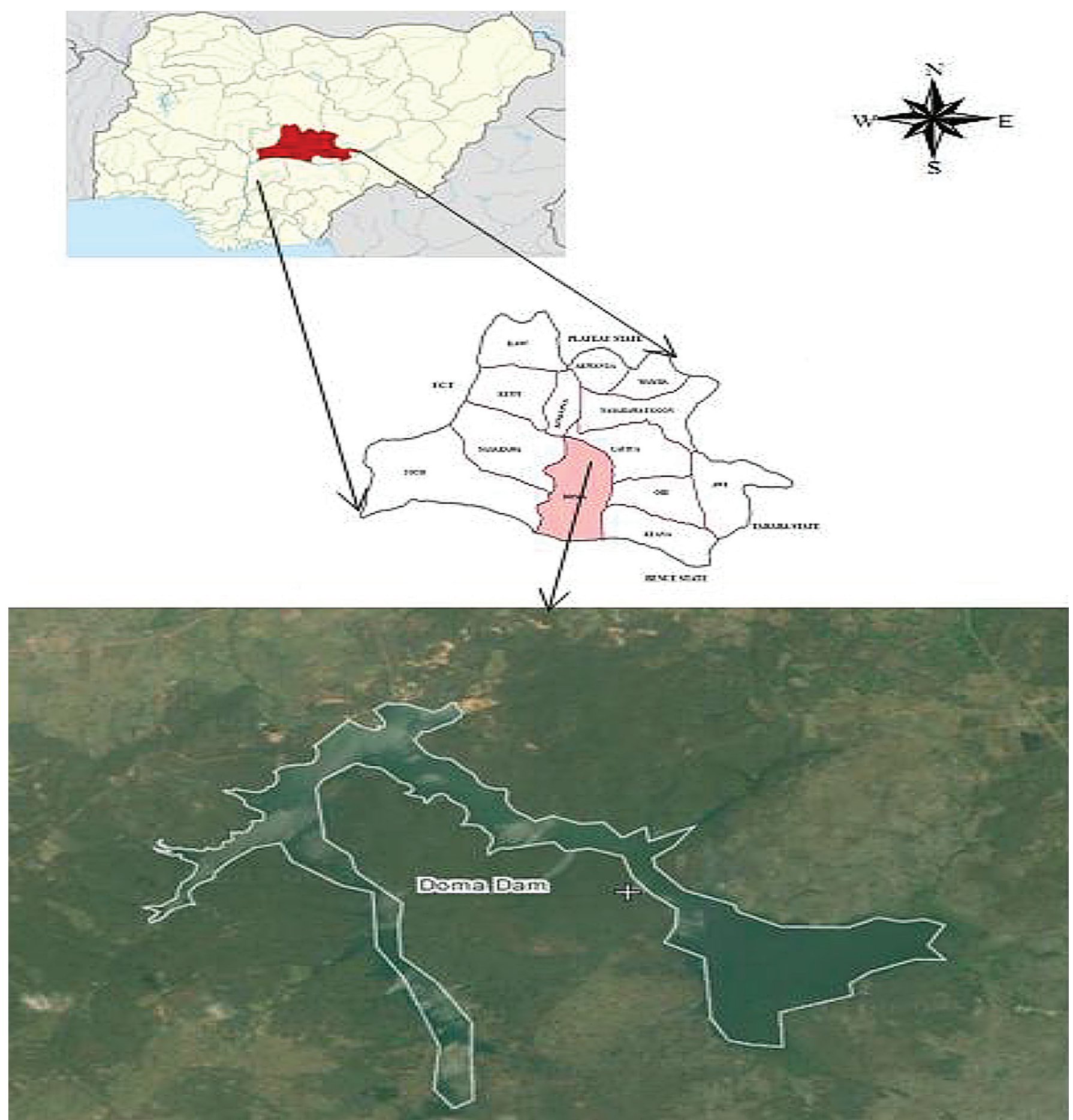

Fig. 1 Map of Nasarawa State Showing the Doma Local Government Area and satellite imagery of the reservoir Source: Yaro and Ebuga (2013).

\section{MATERIALS AND METHODS}

\subsection{Data Collection}

The data collected for this study include hydrological and meteorological data, a layout map of the project area, topographic maps, the monthly irrigation water requirements, the monthly water supply for domestic needs and livestock, and the monthly water for ecological releases. The data are presented in Tab. 2 .

\subsection{Estimation of the hydropower potential using an optimization model}

Optimization methods are basic tools which are useful in reservoir management studies. The problem of optimal reservoir operations consists of obtaining optimal releases, reservoir storage, and downstream reach-routed flows based on the forecasted inflows. In formulating the models, the time step can be hourly, daily, weekly, monthly or yearly. When hydropower operations are coupled with flood control or other uses, daily and hourly time steps are more appropriate. However, when the available data for the analysis are not in an appropriate form, as is the case with the system of interest, then 
Tab. 2 Water requirements and reservoir inflow data

\begin{tabular}{|c|c|c|c|c|c|c|}
\hline Month & $\begin{array}{l}\text { Irrigation } \\
\left(\mathrm{Mm}^{3}\right)\end{array}$ & $\begin{array}{l}\text { Water Supply } \\
\qquad\left(\mathrm{Mm}^{3}\right)\end{array}$ & $\begin{array}{c}\text { Ecological Release } \\
\left(\mathrm{Mm}^{3}\right)\end{array}$ & $\begin{array}{c}\text { Monthly Reservoir } \\
\text { Inflow } \\
\left(\mathrm{Mm}^{3}\right)\end{array}$ & $\begin{array}{l}\text { Direct Rainfall Over } \\
\text { Reservoir }\left(\mathrm{Mm}^{3}\right)\end{array}$ & $\begin{array}{c}\text { Evaporation } \\
\left(\mathrm{Mm}^{3}\right)\end{array}$ \\
\hline January & 2.786 & 0.833 & 0.450 & 0.654 & 0.004 & 0.211 \\
\hline February & 2.598 & 0.833 & 0.450 & 0.464 & 0.005 & 0.196 \\
\hline March & 1.281 & 0.833 & 0.450 & 0.518 & 0.049 & 0.236 \\
\hline April & 0.292 & 0.833 & 0.450 & 1.500 & 0.172 & 0.205 \\
\hline May & 1.163 & 0.833 & 0.450 & 5.020 & 0.34 & 0.192 \\
\hline June & 0.906 & 0.833 & 0.450 & 7.397 & 0.477 & 0.165 \\
\hline July & 0.548 & 0.833 & 0.450 & 13.580 & 0.448 & 0.137 \\
\hline August & 0.496 & 0.833 & 0.450 & 23.604 & 0.62 & 0.141 \\
\hline September & 0.188 & 0.833 & 0.450 & 34.552 & 0.485 & 0.145 \\
\hline October & 0.102 & 0.833 & 0.450 & 24.177 & 0.214 & 0.153 \\
\hline November & 0.529 & 0.833 & 0.450 & 11.409 & 0.017 & 0.199 \\
\hline December & 2.221 & 0.833 & 0.450 & 1.210 & 0.001 & 0.205 \\
\hline Annual Total & 13.110 & 9.996 & 5.400 & 124.086 & 2.832 & 2.185 \\
\hline
\end{tabular}

Source: Lower Benue River Basin Development Authority, Makurdi (2015)

larger time steps must be used. In this study, the objective function and constraints are formulated to derive the operational policies for the reservoir with monthly time steps. For modeling the optimization, the following tasks were carried out: determination of the reservoir yield capacity, estimation of the various probabilities of exceedence of the reservoir inflow, establishment of a relationship between the generating head and reservoir storage, development of an optimization model for the two possible arrangements, and the solution of the model by considering some scenarios.

\subsubsection{Reservoir Yield Capacity Analysis}

The primary purpose of a reservoir is to provide a means of regulating surface water flows so that water can be withdrawn from it in an appropriate quantity and at a time to meet specified needs. The capacity of the reservoir and the water withdrawal strategy determine the extent of the storage for later use. The yield of a reservoir is the amount of water available for use, given the stream flow characteristics and the capacity. The yield determined using the sequent peak procedure, which gives the storage at any time, is presented in equation (1), Locks et al., (2005)

$$
\mathrm{K}_{\mathrm{t}}= \begin{cases}\mathrm{R}_{\mathrm{t}}-\mathrm{Q}_{\mathrm{t}}+\mathrm{K}_{\mathrm{t}-1} ; & \text { if }+\mathrm{ve} \\ 0 ; & \text { otherwise }\end{cases}
$$

where: $\mathrm{Q}_{\mathrm{t}}$ is the inflow volume;

$\mathrm{R}_{\mathrm{t}}$ is the required release,

$\mathrm{K}_{\mathrm{t}-1}$ is the storage capacity required at the beginning of a time period

By setting $\mathrm{K}_{\mathrm{o}}=0$, then $\mathrm{K}_{\mathrm{t}}$ is calculated for the period of record. The required storage is the maximum of all $\mathrm{K}_{t}$ 's to meet the specified release $\mathrm{R}_{\mathrm{t}}$. The procedure is repeated for various release values, and the results are used to obtain the storage yield function presented in Figure 2.

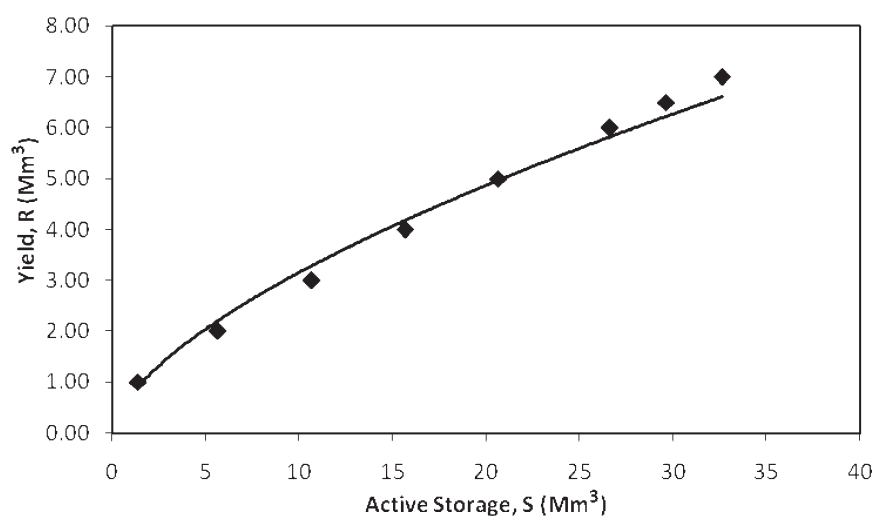

Fig. 2 Storage-Yield function for the Doma reservoir

The maximum monthly yield from the reservoir with a live storage of $30 \mathrm{Mm}^{3}$ was obtained as $6.56 \mathrm{Mm}^{3}$. Thus, the upper limit of the possible optimized total release is $6.56 \mathrm{Mm}^{3}$. The corresponding value of the total releases for live storage of $25 \mathrm{Mm}^{3}$ and $35 \mathrm{Mm}^{3}$ were also determined to be $5.73 \mathrm{Mm}^{3}$ and $7.40 \mathrm{Mm}^{3}$ respectively (Adunkpe, 2016).

\subsubsection{Estimation of the reservoir inflow of various probabilities of exceedence}

The reservoir inflow is fitted to a normal probability distribution based on the monthly mean and standard deviation of the historical data. The normal models obtained for the months of January to December are in the form presented in equation (2).

$$
Q=\widehat{Q}+\sigma K
$$

where

$Q=$ flow of a particular month $\left(\mathrm{Mm}^{3}\right), \widehat{Q}=$ Mean flow $\left(\mathrm{Mm}^{3}\right)$

$\sigma=$ Standard deviation $\left(\mathrm{Mm}^{3}\right)$ and $\mathrm{K}$ is a constant, depending on the probability 
The predicted reservoir inflows of $50 \%, 75 \%$, and $90 \%$, and the probabilities of exceedence are presented in Tab. 3 .

Tab. 3 Reservoir inflows of different reliabilities

\begin{tabular}{llll}
\hline & \multicolumn{3}{l}{ Probability of exceedence } \\
& $50 \%$ & $75 \%$ & $90 \%$ \\
\hline Month & & & \\
Jan & 0.654 & 0.408 & 0.185 \\
Feb & 0.464 & 0.284 & 0.121 \\
Mar & 0.518 & 0.295 & 0.093 \\
Apr & 1.500 & 0.689 & 0.045 \\
May & 5.020 & 3.177 & 1.511 \\
Jun & 7.397 & 4.655 & 2.177 \\
Jul & 13.580 & 7.466 & 1.940 \\
Aug & 23.604 & 14.292 & 5.877 \\
Sept & 34.552 & 21.176 & 9.088 \\
Oct & 24.177 & 16.826 & 10.183 \\
Nov & 11.409 & 5.763 & 0.660 \\
Dec & 1.210 & 0.646 & 0.137 \\
\hline
\end{tabular}

\subsubsection{Generating head as a function of the reservoir's storage}

The elevation and storage data from the topographical map of the Doma reservoir's impounding area and the assumed tail race elevation were used to obtain the relationship between the head and reservoir storage. The tail race elevation was deducted from the reservoir elevation in order to obtain a generating head. The plot of the generating head against the reservoir storage gave equation (3) along with the coefficient of determination $\left(\mathrm{R}^{2}\right)$. (Adunkpe, 2016).

Linear Relationship:

Coefficient of Determination $\left(\mathrm{R}^{2}\right)$ :

$\mathrm{H}=2.008 \mathrm{~S}+5.495$

0.91

\subsection{Formulation of problem of reservoir operations}

\subsubsection{System and description of problem}

The main features of the reservoir system can be briefly summarized as follows:

- The Doma reservoir has a catchment area of $179.94 \mathrm{Km}^{2}$ and a live storage capacity of $30 \mathrm{Mm}^{3}$.

- The purposes of this reservoir system are irrigation, the water supply and ecological releases

- The hydropower is proposed as an additional scheme. (i.e., integration of a hydropower turbine for energy generation). Energy production requires water to drive the turbine and can be released to serve the purposes the reservoir was designed for. However, in this case hydropower is to be integrated in two different arrangements as presented in Figs. 3 and 4 respectively.

\subsubsection{Development of a long-range operational guide for the Doma dam}

The linear programming technique is one of the most widely used mathematical programming techniques in water resources planning and management due to its convenience, particularly in the optimal allocation of scarce resources for various purposes. It has the advantage of being well defined and easy to understand with a readily applicable algorithm; numerous generalized computer programs are available for solving linear programming problems. A model with a monthly time step can be said to describe a long-range operational problem. The historical monthly reservoir inflow was fitted with normal probability distributions in order to predict reservoir inflows of different reliabilities. The stream flow sequences obtained were used to derive the reservoir's operational and management decisions. The optimal monthly releases from the reservoir were determined subject to the available storage using the yield-storage function which had been developed.

The objective function was the maximization of energy, while the reservoir characteristics, the irrigation requirements, the water supply, ecological needs and the non - negative of the hydropower releases are included in the constraints.

\subsubsection{System and problem description for scenario 1}

In this scenario, the Doma reservoir is located at site 1; the irrigation, water supply scheme, hydropower system and ecological release are located at sites 2, 3, 4 and 5 respectively. The release allocated for the hydropower in this scenario is independent of releases for other uses. This arrangement is portrayed in Fig. 2. However, in this case the hydropower is to be integrated so that a separate release of water is allocated for the hydropower plant.

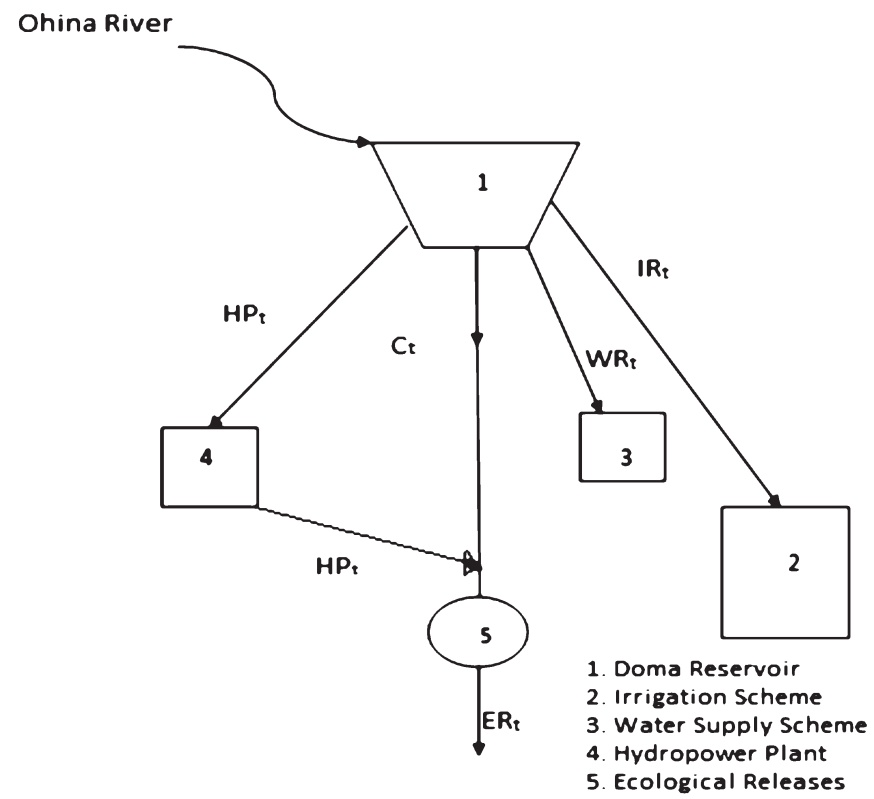

Fig. 2 System Diagram of the study basin for scenario 1

\section{Objective Function}

The objective function, along with the constraints, constitutes the linear programming formulation. The objective function of this optimization process is the maximization of the total annual energy generation $T E$,

$$
T E=\operatorname{Max} \sum_{t=1}^{T=12}\left(E_{t}\right)
$$

The total annual energy generation is a summation of the twelve monthly energy generations $E_{t}$ and $E_{t}$, which are calculated as: 


$$
E_{t}=2.73 H P_{t} H_{t} e(M W H)
$$

where

$$
\begin{aligned}
& H P_{t}=\text { Release for hydropower generation }\left(\mathrm{Mm}^{3}\right) \\
& H_{t}=\text { Generating head }(\mathrm{m}) \\
& e=\text { Efficiency of plant } \\
& t, T=\text { Monthly period } \quad \mathrm{t}=1,2,
\end{aligned}
$$

\section{Model Constraints}

The maximization of the total annual energy generation is subject to the following constraints:

1. Constraints on releases (yield) from the reservoir

Upper limit (Monthly maximum yield from storage-yield analysis)

$$
\begin{gathered}
T R_{t}=W R_{t}+E R_{t}+I R_{t}+H P_{t} \leq 6.56 \\
t=1,2, \quad T=12
\end{gathered}
$$

Lower limit (Ecological demand, minimum releases)

$$
\begin{aligned}
& T R_{t}=W R_{t}+E R_{t}+I R_{t}+H P_{t} \geq 0.45 \\
& t=1,2, \quad T=12
\end{aligned}
$$

where

$T R_{t}=$ Total monthly releases $\left(\mathrm{Mm}^{3}\right)$ from the reservoir, which should not surpass the monthly maximum yield, and must be greater than the ecological needs.

$W R_{t}=$ Monthly water supply for municipal use $\left(\mathrm{Mm}^{3}\right)$

$E R_{t}=$ Monthly ecological releases $\left(\mathrm{Mm}^{3}\right)$

$I R_{t}=$ Monthly irrigation release $\left(\mathrm{Mm}^{3}\right)$

$H P_{t}=$ Monthly release for hydropower generation

\section{Water supply constraint}

The water release for municipal use from the reservoir should be enough to meet the allocation for this purpose.

$$
t=1,2, \quad W R_{t} \geq W_{t} \quad T=12
$$

where $\mathrm{W}_{\mathrm{t}}=$ Monthly water supply demand $\left(\mathrm{Mm}^{3}\right)$

\section{Ecological release constraint}

The release for ecological requirements should be sufficient to meet the ecological demands

$$
t=1,2, \quad E R_{t} \geq E C_{t}, \quad T=12
$$

where $\mathrm{EC}_{\mathrm{t}}=$ Monthly ecological demand $\left(\mathrm{Mm}^{3}\right)$

\section{Irrigation release constraint}

The release for irrigation released during a particular month from the reservoir should be enough to meet the crop water requirement. It should also be greater than than minimum irrigation required.

$$
I R_{t} \geq I_{t} T=12
$$

where $\mathrm{I}_{\mathrm{t}}=$ Monthly irrigation demand $\left(\mathrm{Mm}^{3}\right)$

\section{Non- negative constraint for hydropower release}

The amount of water discharged for hydropower generation should be non-negative

$$
H P_{t} \geq 0
$$

$\mathrm{t}=1,2$,

\section{Reservoir storage capacity constraint}

The available water in the reservoir should not exceed the reservoir's life storage capacity but must be greater than the dead storage capacity $\left(\mathrm{Mm}^{3}\right)$ for the whole time period. The live storage in the reservoir should be less than or equal to the maximum capacity for all the time periods.

$$
\begin{aligned}
& t=1,2, \quad S_{t} \leq 30 \quad T=12 \\
& S_{t} \geq 7.5 \\
& t=1,2, \quad T=12
\end{aligned}
$$

where $\mathrm{S}_{\mathrm{t}}=$ reservoir storage $\left(\mathrm{Mm}^{3}\right)$ during release

\section{Continuity of the mass balance constraint}

The mass balance between the inflow into the reservoir and the releases from the reservoir make up the continuity constraints. These constraints relate to the total releases, the reservoir storage, inflows into the reservoir, overflows and the evaporation losses for all the time periods. The reservoir storage continuity relationship is expressed as:

$$
\begin{array}{rc}
S_{t+1}=S_{t}+Q_{t}-T R_{t}-X_{t}-G_{t} \\
t=1,2, & T=12
\end{array}
$$

where

$\mathrm{S}_{\mathrm{t}+1}=$ final reservoir storage at the end of the month $\left(\mathrm{Mm}^{3}\right)$

$\mathrm{S}_{\mathrm{t}}=$ initial reservoir storage at the beginning of the month $\left(\mathrm{Mm}^{3}\right)$

$\mathrm{Q}_{\mathrm{t}}=$ monthly reservoir inflow $\left(\mathrm{Mm}^{3}\right)$

$\mathrm{TR}_{\mathrm{t}}=$ total monthly releases $\left(\mathrm{Mm}^{3}\right)$

$\mathrm{X}_{\mathrm{t}}=$ monthly evaporation losses $\left(\mathrm{Mm}^{3}\right)$

$\mathrm{G}_{\mathrm{t}}=$ monthly overflow if available

This is the general optimization model's formulation in scenario 1. The monthly model is fully established and solved using LINGO 15.0. The model's solutions were determined in two categories. The results of the optimization showing the energy output are presented in Tab. 4.

Tab. 4 Summary of the hydropower potential (scenario 1)

\begin{tabular}{lllll}
\hline $\begin{array}{l}\text { Upper limit } \\
\text { Release }\left(\mathrm{Mm}^{3}\right)\end{array}$ & $\begin{array}{l}\text { Storage } \\
\left(\mathrm{Mm}^{3}\right)\end{array}$ & \multicolumn{4}{l}{ Hydropower for flows of different } \\
& & $50 \%$ & $75 \%$ & $90 \%$ \\
\hline 6.56 & 30.00 & 4650.21 & 3939.70 & 2545.18 \\
7.00 & 32.63 & 5337.32 & 4415.51 & 3036.11 \\
\hline
\end{tabular}

\subsubsection{System and description of problem for scenario 2}

In this scenario, hydropower is to be integrated as indicated in Fig. 3, so that the whole of the available flow is used to turn the turbine, after which diversion for various other uses can be performed. This is the optimum arrangement since the turbine only needs water for turning purposes and can be completely released for other users. This arrangement must be incorporated in the main design at the inception of the project for effective implementation.

\section{Objective function}

The objective function is the maximization of the total annual energy generation $z$, as presented in equations (4) and (5). This has also been adopted, and the constraints for scenario 2 are given as follows:

\section{Model constraints}

The constraints in equations (8) - (14) are also applicable in this scenario, but the constraints on the upper and lower releases change 


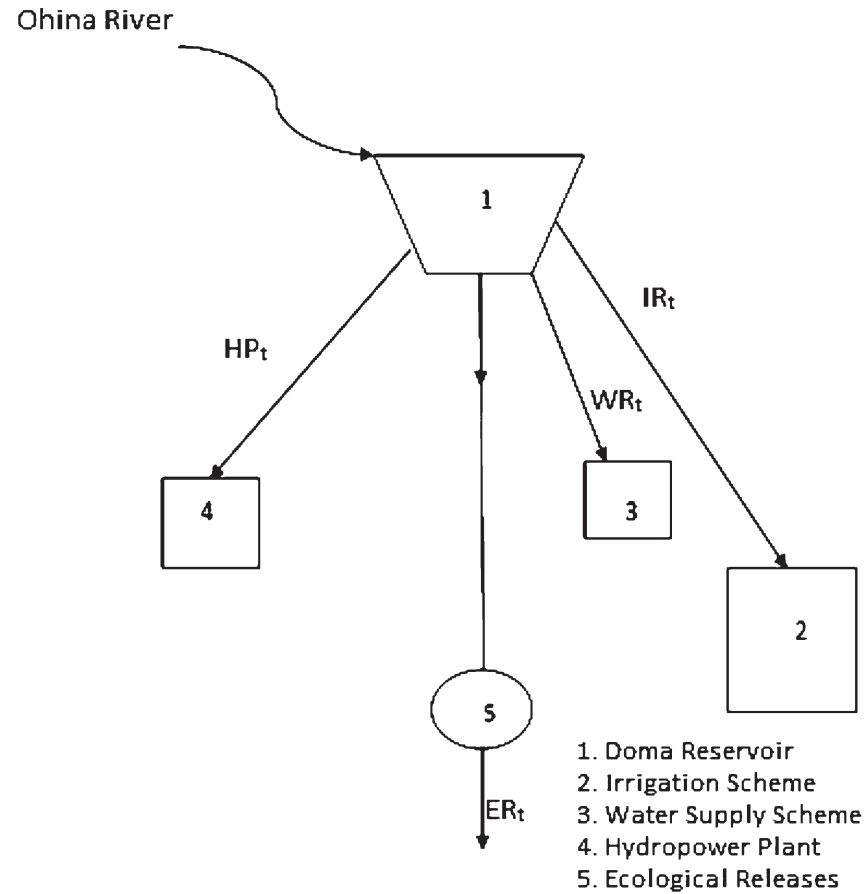

Fig. 3 System Diagram of the study basin for scenario 2

due to the complimentary releases added and presented in equations (15) and (16) respectively. Also, there is a need to incorporate a constraint on releases (equilibrium) from the reservoir as presented in equation (17).

Upper Limit (Monthly maximum yield from the storage-yield analysis)

$$
T R_{t}=W R_{t}+I R_{t}+C_{t}+H P_{t} \leq 6.561
$$

Lower Limit (Ecological demands, minimum releases)

$$
T R_{t}=W R_{t}+I R_{t}+C_{t}+H P_{t} \geq 0.45
$$

Constraints on release (equilibrium) from the reservoir

$$
C_{t}+H P_{t} \geq E R_{t}
$$

where

$C_{t}=$ Complimentary releases $\left(\mathrm{Mm}^{3}\right)$

Other terms are as previously described.

The results of the optimization model for scenario 2 are presented in Tab 5 .

Tab. 5 Summary of hydropower potential (Scenario 2)

\begin{tabular}{lllll}
\hline \multirow{2}{*}{$\begin{array}{l}\text { Upper limit } \\
\text { Release }\left(\mathrm{Mm}^{3}\right)\end{array}$} & $\begin{array}{l}\text { Storage } \\
\left(\mathrm{Mm}^{3}\right)\end{array}$ & \multicolumn{3}{l}{ Hydropower for flows of different } \\
& & $50 \%$ & $75 \%$ & $90 \%$ \\
\hline 6.56 & 30.00 & 5389.13 & 4439.37 & 3032.01 \\
7.00 & 32.63 & 6122.50 & 5070 & 3560.16 \\
\hline
\end{tabular}

\section{RESULTS AND DISCUSSION}

\subsection{Water resources of the Doma dam}

The information obtained revealed that the Doma dam has a catchment area of $179.94 \mathrm{~km}^{2}$ with a maximum reservoir capacity of $37.5 \mathrm{Mm}^{3}$ at a normal water level with a surface area of $2.20 \mathrm{~km}^{2}$. The dam has live storage and dead storage of $30 \mathrm{Mm}^{3}$ and $7.5 \mathrm{Mm}^{3}$ respectively. Detailed information on the dam was presented in Tab. 1. The information on the reservoir capacity revealed that the dam has more than the required storage for the primary purposes.

The water requirements for various purposes and river flow data as obtained from the Lower Benue River Basin Development Authority, Markurdi (LBRBRDA), are presented in Table 2. The information in Tab. 2 revealed a total irrigation requirement of $13.11 \mathrm{Mm}^{3}$; the total water required for the water supply is about $10.00 \mathrm{Mm}^{3}$ and the total reservoir inflow of $124.09 \mathrm{Mm}^{3}$. A difference of about 0.65 $\mathrm{Mm}^{3}$ was observed between the direct rainfall and evaporation over the reservoir, which implies an annual water surplus of $0.65 \mathrm{Mm}^{3}$ on the surface of the reservoir.

\subsection{Optimization modeling}

Optimization modeling was adopted to ascertain the hydropower energy that can be obtained after considering the releases of sufficient water for the primary uses. In carrying out the optimization modeling, the following were determined:

(i) The reservoir yield capacity of the dam was determined to be $6.56 \mathrm{Mm}^{3}$. This implies that the maximum monthly draft of $6.56 \mathrm{Mm}^{3}$ can be sustained by the reservoir of $30 \mathrm{Mm}^{3}$ live storage as built (Scenario 1), while the draft of $7.0 \mathrm{Mm}^{3}$ can be sustained by the reservoir of $32.63 \mathrm{Mm}^{3}$ capacity (Scenario 2).

(ii) The monthly reservoir inflows with exceedence probabilities of $50 \%, 75 \%$, and $90 \%$ were determined and presented in Tab. 3.

(iii) The relationship between the generating head and reservoir storage was established since the generating head depends on the storage in the reservoir. This was adopted in the energy equation's formulation.

The optimization model has a maximization of hydropower generation as the objective function, while the reservoir's characteristics and other purposes are included in the constraints. The model formulated was solved using LINGO software. The model solution of the hydropower potential for various reservoir inflows of $50 \%, 75 \%$ and $90 \%$ are presented in Tables 4 and 5 for Scenarios 1 and 2 respectively.

\subsection{Power generation for the scenarios}

\subsubsection{Scenario 1}

The following inferences were drawn from the study based on scenario 1 .

- The study establishes that the monthly maximum draft is 6.56 $\mathrm{Mm}^{3}$ with a live storage of $30 \mathrm{Mm}^{3}$, while it is $7.0 \mathrm{Mm}^{3}$ with a storage capacity of $32.63 \mathrm{Mm}^{3}$. 
- The hydropower energy obtained with the upper limit of the release of $6.56 \mathrm{Mm}^{3}$ and the live storage of $30 \mathrm{Mm}^{3}$ under reservoir inflows of $50 \%, 75 \%$, and $90 \%$ probabilities of exceedence is $4650.21 \mathrm{MWH}$ (0.53 MW), $3939.70 \mathrm{MWH}(0.45$ $\mathrm{MW})$, and 2545.18 MWH (0.29 MW) respectively.

- The hydropower energy obtained with the upper limit of the release of $7.0 \mathrm{Mm}^{3}$ and the storage capacity of $32.63 \mathrm{Mm}^{3}$ under reservoir inflows of $50 \%, 75 \%$, and $90 \%$ probabilities of exceedence is $5337.32 \mathrm{MWH}(0.61 \mathrm{MW}), 4415.51 \mathrm{MWH}(0.51)$, and 3036.11 MWH (0.35 MW) respectively.

\subsubsection{Scenario 2}

The following inferences were drawn from the study based on scenario 2 .

- The hydropower energy obtained with the upper limit of the release of $6.56 \mathrm{Mm}^{3}$ and the live storage of $30 \mathrm{Mm}^{3}$ under reservoir inflows of $50 \%, 75 \%$, and $90 \%$ probabilities of exceedence is $5389.13 \mathrm{MWH}(0.62 \mathrm{MW}), 4439.37 \mathrm{MWH}$ (0.51 $\mathrm{MW})$ and $3032.01 \mathrm{MWH}(0.35 \mathrm{MW})$ respectively.

- The hydropower energy obtained with the upper limit of the release of $7.0 \mathrm{Mm}^{3}$ and the live storage of $32.63 \mathrm{Mm}^{3}$ under reservoir inflow of $50 \%, 75 \%$, and $90 \%$ probabilities of exceedence is $6122.50 \mathrm{MWH}(0.70 \mathrm{MW}), 5070.00 \mathrm{MWH}(0.58$ $\mathrm{MW})$, and3560.16 MWH (0.41 MW) respectively

The trend is that the greater the probability of exceedence (reliability), the smaller the reservoir inflow and the smaller the hydropower energy that can be generated.

\section{CONCLUSIONS AND RECOMMENDATION}

\subsection{Conclusions}

It can be concluded that the optimal energy generation potential of the Doma dam is 5337.32 MWH (0.61MW) and 6122.50 MWH $(0.70 \mathrm{MW})$ for scenarios 1 and 2 respectively. Thus the Doma dam is suitable for the production of hydroelectric power. The hydropower generated would enhance the quality of life of the people living in the Doma community and improve the Doma irrigation scheme. This will eventually lead to a reduction in poverty since jobs will be available as small-scale industries spring up.

\subsection{Recommendation}

Based on the outcome of the study it is recommended that the site be found suitable for a small hydropower scheme and that three turbines of $300 \mathrm{KW}(0.30 \mathrm{MW})$ capacities each can be installed at the Doma dam for hydropower generation. 


\section{REFERENCES}

Adejumobi, I. A. and Adebisi, O. I. (2011) Equipment Selection for a Sustainable Small Hydropower Scheme. Top Research Group Conference, Lome, Togo 2011.

Adunkpe, T. L. (2016) Assessment of the Hydropower Potential of Doma Dam for electricity generation. A M.Eng. A Project Submitted to the Department of Civil Engineering, Faculty of Engineering and Technology, University of Ilorin, Ilorin, Kwara State, Nigeria

Arunkumar, R. and Jothiprakash, V. (2012) Multi-reservoir Optimization for Hydropower Production Using Non Linear Programming Technique. Journal of the Institution of Engineers (India), Vol. 93(2) pp: 111-120.

Braimoh, D. S. and Okedeyi, A. S. (2010) Energy and Power Generation, Transmission and Distribution in Lagos State. Retrieved from http://cefolassaocoed.net/index.php?option=com content $\&$ view $=$ article $\&$ id $=83 \&$ Itemid $=88 \&$ limitstart $=4$ on $15 /$ $06 / 2015$

Kareem, R. O., Bakare, H. A., Raheem, K. A., Bashir, N. O., Ademoyewa, G. and Arije, A. R. (2014) Econometric Analysis of Electricity Consumption, Capacity Utilization and Economic Growth in Nigeria: A Disaggregated Analysis. Journal of Economics and Sustainable Development, Vol.5 (4) pp: 170 - 178.

Kennedy - Darling, J., Hoyt, N., Murao, K. and Ross, A., (2008) The Energy Crisis of Nigeria: An Overview and Implications for the Future, University of Chicago.

Latham and Watkins (2016) Nigerian Power Sector: Opportunities and Challenges for

Investment in 2016. Client Alert White Paper, February 23, 2016 No. 1930

Loucks, D. P., Eelco, V. B., Jery, R. S., Jozef, P. M., AND Villars, M. T. (2005) Water Resources Systems Planning and Management. An Introduction to Methods, Models and Applications. Published by the United Nations Educational Scientific and Cultural Organization (UNESCO).
Manohar, K. and Adeyanju, A. A. (2009) Hydro Power Energy Resources in Nigeria. Journal of Engineering and Applied Sciences, Vol. 4 (1), pp: 68-73.

National bureau of statistics (2010) Annual Abstract of Statistics, 2010. Retrieved from http:/www.nigerianstat.gov.ng/ on $23 / 12 / 2014$

Okoro, M. C. (2006) Rivers in Nigeria and Corresponding Hydro Potential. Proceedings of Conference on National Workshop on Capacity Building in Small River Planning and Design for Isolated Off-Grid Electricity Generation. Channel View Hotel, Calabar, $14^{\text {th }}$ Nov.2006, pp: 82-87.

Unido-shp annual report (2012) United Nations Development Organization, Regional Centre for West Africa Small Hydro Power, Abuja: Annual Report. Retrieved from http://unidorc.org/nigeria/n_nigcapacity.htm on 14/09/2015

Salami, A. W. and Sule, B. F (2012) Optimal Water Management Modeling for Hydropower System on River Niger in Nigeria. Annals of Faculty of Engineering Hunedoara, International Journal of Engineering. Tome X (year 2012)-FASCICULE (ISSN 15842665) 185-192. Available online http://annals.fih.upt.ro/pdffull/2012/ANNALS-201.

Sambo, A. S., Garba, B., Zarma, I. H. and Gaji, M. M. (2009) Electricity Generation and the Present Challenges in the Nigerian Power Sector. Energy Commission of Nigeria, Abuja-Nigeria

Sule, B. F. (2003) “Water Security: Now and the Future”, $65^{\text {th }}$ Inaugural Lecture, University of Ilorin, Ilorin, Nigeria.

Yaro, O. O., and Ebuga, E. A. (2013) An Assessment of the Development Potentials of Nasarawa State in Nigeria. International Journal of Environmental Science, Toxicology and Food Technology, Vol. 6(1) pp: 1-5

Zarma, I. H. (2006) Hydropower Resources in Nigeria. Country position paper presented at 2nd Hydro Power for Today conference, International Centre on Small Hydro Power (IC-SHP), Hangzhou, China. Retrieved from; http://www.Unido.Org/Fileadmin/ Import/52413_Mr._Ismaila_Haliru_Zarma.Pdf on 02/12/14

\section{Brief sketch of the lead author with background:}

Dr Salami completed his $\mathrm{PhD}$ at the Department of Civil Engineering, University of Ilorin, Nigeria in 2007. His teaching \& research areas are Water Resources, Hydro-Climatology and Environmental Engineering with over fifty publications in reputable journals both national and international. A visiting scholar at the New York State University, Buffalo and North Carolina State University, Raleigh, USA under Fulbright Scholarship from June 2006 to May 2007. A Research Associate at the Department of Civil Engineering and Surveying, Durban University of Technology, Durban, South Africa from February 2013 to August 2014.

$\mathrm{He}$ has been lecturing in the department of Civil Engineering since August 2000 and has been the Sub-Dean of the Faculty of Engineering \& Technology, head of Civil Engineering Department and Coordinator of National Water Resources Capacity Building Network (NWRCBNet-NC) Centre. He is currently an Associate Professor at the Department of Water Resources \& Environmental Engineering, University of Ilorin, Nigeria. 